\title{
Kadar Interleukin-18 pada Kultur Limfosit Penderita Dermatitis Atopik yang Distimulasi Staphylococcal Enterotoxin B (SEB)
}

\author{
Oki Suwarsa, ${ }^{1}$ Sudigdoadi, ${ }^{1}$ Endang Sutedja, ${ }^{1}$ Ponpon Idjradinata ${ }^{2}$ \\ ${ }^{1}$ Departemen Ilmu Kesehatan Kulit dan Kelamin Fakultas Kedokteran Universitas Padjadjaran/Rumah Sakit \\ Dr. Hasan Sadikin Bandung, ${ }^{2}$ Departemen Ilmu Kesehatan Anak Fakultas Kedokteran Universitas Padjadjaran/ \\ Rumah Sakit Dr. Hasan Sadikin Bandung
}

\begin{abstract}
Abstrak
Staphylococcus aureus (S. aureus) mempunyai peranan penting pada patogenesis dermatitis atopik (DA). Peran $S$. aureus tersebut tidak hanya sebagai pencetus DA, tetapi juga menyebabkan inflamasi kronik. Peran tersebut berhubungan dengan dihasilkannya protein antara lain toksin poten oleh S. aureus, yaitu Staphylococcal enterotoxin $B$ (SEB). Interleukin-18 (IL-18) merupakan regulator penting dari produksi sitokin Th-1 yaitu interferon- $\gamma($ IFN- $\gamma)$. Tujuan penelitian ini adalah mengetahui kadar IL-18 pada kultur limfosit pasien DA yang distimulus dengan SEB. Penelitian ini dilakukan pada 20 orang penderita DA (7 laki-laki dan 13 perempuan) dan 20 orang sehat (9 laki-laki dan 11 perempuan) di Rumah Sakit Dr. Hasan Sadikin Bandung, merupakan penelitian eksperimental secara in vitro pada kultur ilmfosit yang distimulus dengan SEB di Laboratorium Penelitian dan Pengujian Terpadu Universitas Gadjah Mada. Terjadi peningkatan kadar IL-18 rata-rata pada kultur limfosit antara sebelum dipapar dan setelah dipapar SEB, baik pada kelompok DA maupun kelompok kontrol. Setelah dilakukan uji statistik perbandingan antara kadar IL-18 rata-rata sebelum dan sesudah dipapar SEB antara kelompok DA dan kontrol, didapatkan hasil kadar IL-18 kelompok DA lebih tinggi bermakna dibanding dengan kelompok kontrol $(\mathrm{p}<0,05)$ sehingga dapat disimpulkan kadar IL-18 meningkat tinggi pada kelompok DA yang dipapar SEB. [MKB. 2015;47(4):249-54]
\end{abstract}

Kata kunci: Dermatitis atopik, interleukin-18 (IL-18), Staphylococcus enterotoxin B

\section{Interleukin-18 Levels in Lymphocytes Cultures from Atopic Dermatitis Patients Stimulated by Staphylococcal Enterotoxin B}

\begin{abstract}
Staphylococcus aureus (S. aureus) has an important role in the pathogenesis of atopic dermatitis (AD). S. aureus acts as a triggering factor for $\mathrm{AD}$ and also causes chronic inflammation. These roles of $\mathrm{S}$. aureus are related to various proteins such as Staphylococcal enterotoxin B (SEB) as a potent toxin. Interleukin-18 (IL-18) is an important regulator of cytokine production of Th-1, which is interferon- $\gamma$ (IFN- $\gamma$ ). The aim of this study was to reveal the levels of IL-18 in cultured lymphocytes from AD patients exposed by SEB. This study was conducted on 20 people with DA (7 men and 13 women) and 20 healthy volunteers ( 9 men and 11 women) in dr. Hasan Sadikin General Hospital. The in vitro experimental study on cultured lympocytes exposed with SEB was performed at the Integrated Research and Testing Laboratory of Gadjah Mada University. The average levels of IL-18 in cultured lymphocytes before and after being exposed to SEB increased both in AD group and control group. After the statistical tests was performed on the ratio of the average levels of IL-18 before and after being exposed to SEB between AD and control groups, it was shown that the levels of IL-18 AD group was significantly higher than the control group $(p<0.05)$. Therefore, it can be concluded that the levels of IL-18 increased higher in AD group exposed by SEB.[MKB. 2015;47(4):249-54]
\end{abstract}

Key words: Atopic dermatitis , interleukin-18, Staphylococcal enterotoxin B

Korespondensi: Dr. Oki Suwarsa, dr., Sp KK(K)., M.Kes Departemen Ilmu Penyakit Kulit dan Kelamin Fakultas Kedokteran Universitas Padjadjaran/Rumah Sakit Dr. Hasan Sadikin Bandung, Jalan Pasteur No. 38 Bandung, mobile 08122357949 e-mail okispkk@yahoo.co.id 


\section{Pendahuluan}

Dermatitis atopik (DA) adalah suatu penyakit kulit yang bersifat kronik dan berulang, pada umumnya terjadi pada anak-anak. Dermatitis atopik sering dikaitkan dengan abnormalitas fungsi kulit sebagai barier, sensitisasi alergen, dan infeksi kulit berulang. ${ }^{1}$

Dermatitis atopik (DA) merupakan penyakit inflamasi pada kulit dengan keluhan rasa gatal yang hebat akibat interaksi kompleks antara gen yang dicurigai mengakibatkan kerusakan barier kulit, kerusakan pada sistem imun bawaan, dan respons imun yang tinggi terhadap alergen dan antigen mikroba. Selain itu, kerusakan barier epidermal bisa juga disebabkan oleh paparan protease dari luar (eksogen) yaitu protease yang berasal dari tungau debu rumah atau S. aureus. ${ }^{1}$

Berdasarkan hasil suatu penelitian diketahui bahwa terjadinya eksaserbasi pada pasien DA, salah satunya disebabkan toksin yang dihasilkan S. aureus. Penelitian terakhir memperlihatkan bahwa eksaserbasi dan inflamasi terus menerus pada DA disebabkan oleh toksin S. aureus yang memiliki peran sebagai superantigen. Toksin stafilokokus (superantigen) telah diidentifikasi dengan imunofluorosens, dan ternyata toksin tersebut ditemukan pada lapisan dermis di kulit seperti infiltrasi sel inflamasi. Toksin poten ini menempel langsung pada molekul reseptor sel $\mathrm{T}$, tanpa diproses oleh antigen presenting cell (APC) dan akan menginduksi APC seperti sel Langerhans dan makrofag serta keratinosit untuk menyekresikan berbagai sitokin. Stimulasi sel $\mathrm{T}$ oleh superantigen akan menyebabkan sel $\mathrm{T}$ teraktivasi dan akan menyekresikan sitokin yaitu interleukin-1 (IL-1), IL-6, dan tumor necrosis factor- $\alpha$ (TNF- $\alpha$ ), yang menyebabkan inflamasi. ${ }^{1}$ 2

Pada DA akut yang berperan terutama adalah Th-2, sedangkan pada DA kronik keseimbangan akan bergeser ke arah Th-1. Sel Th-1 akan menyekresikan sitokin IL-12 dan IFN- $\gamma$ yang akan mengaktivasi keratinosit untuk menghasilkan TNF- $\alpha$, sehingga terjadi reaksi inflamasi. TNF- $\alpha$ juga akan menyebabkan migrasi limfosit dan sel PMN dari sirkulasi ke daerah inflamasi, sehingga secara klinis pada DA kronik tampak papula, plak hiperpigmentasi, disertai skuama yang terasa gatal. ${ }^{1}$ Produksi IFN- $\gamma$ telah diketahui distimulasi oleh IL-18, merupakan sitokin Th-1, yang disekresikan oleh makrofag dan keratinosit. Kadar IL-18 meningkat pada DA dan diduga berhubungan dengan kolonisasi S. aureus. ${ }^{3}$

Tujuan penelitian ini adalah mengetahui peningkatan kadar sitokin IL-18 pada kultur limfosit pasien DA yang distimulus dengan Staphylococcal enterotoxin B (SEB).

\section{Metode}

Penelitian ini merupakan penelitian analitik eksperimental, memakai desain kasus-kontrol, membandingkan kadar IL-18 rata-rata total antara kelompok DA dan kontrol. Pemeriksaan klinis dilakukan di poliklinik Divisi Alergi dan Imunologi Departemen Ilmu Kesehatan Kulit dan Kelamin RSUP Dr. Hasan Sadikin/Fakultas Kedokteran Universitas Padjadjaran Bandung. Pemeriksaan untuk kultur limfosit, pemaparan dengan Staphylococcal enterotoxin B (SEB), serta pengukuran kadar IL-18 dilakukan di Laboratorium Penelitian dan Pengujian Terpadu Universitas Gadjah Mada Yogyakarta.

Subjek penelitian adalah pasien DA yang memenuhi kriteria inklusi dan tidak termasuk kriteria eksklusi. Kriteria inklusi adalah: laki-laki dan wanita dengan usia $>2$ tahun; penderita DA yang didiagnosis berdasarkan kriteria HanifinRajka. Kriteria eksklusi adalah penderita DA yang sedang memakai kortikosteroid sistemik atau topikal dalam 2 minggu terakhir; penderita DA yang sedang mempergunakan antibiotik sistemik atau topikal dalam 2 mingggu terakhir; penderita penyakit atopi lain selain DA, yaitu asma bronkiale, rinitis alergika, dan hay fever. Kelompok kontrol adalah orang sehat lakilaki dan wanita berusia $>2$ tahun serta usia disesuaikan dengan kelompok DA. Semua subjek penelitian bersedia mengikuti dalam penelitian dengan menandatangani persetujuan (informed consent). Objek penelitian adalah kultur limfosit yang diperoleh dari hasil isolasi limfosit dari darah perifer dengan metode Ficoll histopaque density gradient yang berasal dari kelompok DA dan kontrol.

Besar sampel dihitung menggunakan rumus uji hipotesis beda dua kelompok rata-rata tidak berpasangan. JumLah subjek penelitian adalah 20 untuk tiap kelompok. Sampel diambil secara consecutive sampling. Pengukuran kadar sitokin dari supernatan kultur limfosit menggunakan kit ELISA Quantikine human IL-18 (bioLegend, Inc), sedangkan pembacaan hasil menggunakan ELISA reader. Staphylococcal enterotoxin B yang digunakan berasal dari $R \& D$ Systems.

Darah perifer diambil dari kelompok DA dan kontrol sebanyak $5 \mathrm{~mL}$. Sampel darah diambil mempergunakan vacutainer yang mengandung heparin (2.000 U heparin dalam $1 \mathrm{~mL}$ ), kemudian dibawa dengan menggunakan termos vaksin 
Tabel 1 Homogenitas Karakteristik Subjek

\begin{tabular}{lccc}
\hline \multicolumn{1}{c}{ Karakateristik } & $\begin{array}{c}\text { DA } \\
(\mathbf{n = 2 0})\end{array}$ & $\begin{array}{c}\text { Kontrol } \\
(\mathbf{n = 2 0})\end{array}$ & Kemaknaan \\
\hline Jenis kelamin & & & \\
$\quad$ Laki-laki & 7 & 9 & $\mathrm{x}^{2}=0,417$ \\
$\quad$ Perempuan & 13 & 11 & $\mathrm{p}=0,519$ \\
Usia (tahun) & & & \\
$\mathrm{X}+(\mathrm{SD})$ & $23,05 \pm 12,14$ & $22,60 \pm 10,94$ & $\mathrm{p}=0,0903$ \\
Rentang & $7-55$ & $7-48$ & \\
\hline
\end{tabular}

Keterangan: $\bar{x} \bar{x}=$ Rata-rata; DA=Dermatitis atopik; $\mathrm{x}^{2}=$ chi-kuadrat; $\mathrm{n}=\mathrm{jumlah}$ sampel; $\mathrm{p}=$ kemaknaan; $\mathrm{SD}=$ standard deviation

berisi ice pack ke Laboratorium Penelitian dan Pengujian Terpadu Universitas Gadjah Mada Yogyakarta, untuk diproses lebih lanjut sebelum 24 jam.

Setelah sampai di Laboratorium Penelitian dan Pengujian Terpadu Universitas Gadjah Mada Yogyakarta, dilakukan isolasi limfosit dari sampel darah. Penanaman limfosit dilakukan pada 12x8 sumur (well) microplate. Pada tiap sampel, dikelompokkan menjadi 2 kelompok sumur yang berbeda, yaitu sumur pertama tidak dipapar dan sumur kedua dipapar dengan SEB, kemudian diinkubasi dalam inkubator $\mathrm{CO}_{2}$ dalam suhu $37^{\circ} \mathrm{C}$, dan dilakukan panen setelah hari ketiga. Semua reagen dan sampel disiapkan dalam temperatur kamar, kemudian dilakukan prosedur pemeriksaan ELISA untuk mengukur kadar IL-18 pada keadaan tidak dipapar dan dipapar menggunakan SEB. Setiap pemeriksaan tersebut dilakukan sebanyak dua kali (duplo). Hasil pengukuran itu dinyatakan dalam optical density (OD), selanjutnya dikonversi menjadi pikogram per milliliter $(\mathrm{pg} / \mathrm{mL})$ menurut standar. Data yang diperoleh dicatat dalam formulir penelitian, kemudian dilakukan penyuntingan, verifikasi, coding, dan data entry, selanjutnya dilakukan dengan analisis data.

Analisis statistik dimulai dengan memakai uji kesetaraan, yaitu usia dan jenis kelamin. Usia adalah data numerik sehingga uji kesetaraan adalah uji-t (jika data berdistribusi normal) atau uji Mann-Whitney bila data tidak berdistribusi normal. Jenis kelamin adalah data kategorik sehingga uji kesetaraan proporsi menggunakan uji chi-kuadrat. Untuk menentukan perbedaan antara kelompok DA dan kontrol untuk semua parameter dipakai uji Mann-Whitney.

Penelitian ini telah disetujui oleh Komite Etik Fakultas Kedokteran Universitas Padjadjaran/ RS Dr. Hasan Sadikin Bandung dan setiap subjek dalam penelitian ini telah diberi informasi dan sudah menandatangani persetujuan (informed consent). Beda kadar IL-18 rata-rata total kedua kelompok dianalisis dengan menggunakan uji hipotesis Mann-Whitney tidak berpasangan.

\section{Hasil}

Subjek penelitian ini adalah 20 pasien DA dan 20 kontrol. Pada tabel 1 menunjukkan bahwa karakteristik kelompok penelitian dengan uji Shapiro Wilk, tidak memperlihatkan perbedaan bermakna ( $p>0,05)$, berdasarkan komparabilitas ini maka layak diperbandingkan. Pada Tabel 2 terlihat bahwa secara anamnestik 20 orang penderita DA, ditemukan 15 orang yang telah menderita DA lebih dari 1 tahun, sedangkan 5 orang kurang dari 1 tahun. Pada Tabel 3 tampak bahwa kadar IL-18 rata-rata pada yang diberi Staphylococcal enterotoxin B (SEB) lebih tinggi $(99,38 \mathrm{pg} / \mathrm{mL})$, bila dibanding dengan sebelum diberikan paparan (TP), yaitu $54,62 \mathrm{pg} / \mathrm{mL}$. Berdasarkan uji statistik menggunakan uji MannWhitney, maka perbedaan ini sangat bermakna $(\mathrm{p}<0,01)$.

Pada Tabel 4 terlihat bahwa kadar IL-18 rata-rata pada yang diberi (SEB) lebih tinggi $(54,18955 \mathrm{pg} / \mathrm{mL})$ apabila dibanding dengan

Tabel 2 Riwayat Penyakit pada Penderita DA

\begin{tabular}{cc}
\hline Lama Menderita & $\begin{array}{c}\text { Kelompok DA } \\
\text { (n) }\end{array}$ \\
\hline$<1$ th & 5 \\
$\geq 1$ th & 15 \\
Total & 20 \\
\hline
\end{tabular}


Tabel 3 Perbandingan kadar IL-18 Kultur Limfosit Kelompok DA antara Sebelum diberikan Paparan SEB (TP) dengan Setelah Paparan SEB

\begin{tabular}{lccc}
\hline & \multicolumn{3}{c}{ Kadar IL-18 (pg/mL) } \\
\cline { 2 - 4 } & TP & SEB & Kemaknaan \\
\hline Rata-rata & 54,62 & 99,38 & $\mathrm{Z}=-3,715^{\mathrm{a}}$ \\
Simpangan baku & 42,18 & 112,74 & $\mathrm{p}=0,000$ \\
\hline
\end{tabular}

Keterangan: $\mathrm{TP}=$ sebelum diberikan paparan, $\mathrm{SEB}=$ setelah diberikan paparan $\mathrm{SEB}, \mathrm{p}=$ kemaknaan

sebelum diberikan paparan (TP), yaitu 33,36 pg/ mL. Berdasarkan uji statistik memakai uji MannWhitney, perbedaan ini tidak bermakna $(\mathrm{p}>0,05)$. Pada penelitian ini tampak bahwa pada DA, kadar IL-18 rata-rata TP 54,62 dan SEB 99,38. Pada kontrol kadar IL-18 rata-rata TP 33,36 dan SEB 54,19. Berdasarkan atas perhitungan uji statistik Mann Whitney maka kadar IL-18 penderita DA lebih tinggi bermakna dibanding dengan kontrol $(\mathrm{p}<0,05$ dan SEB, $\mathrm{p}<0,05)$.

Pada Tabel 6 tampak bahwa kadar IL-18 ratarata TP $54,6242 \mathrm{pg} / \mathrm{mL}$ untuk yang sebelum diberikan paparan (TP) dan SEB 99,38 pg/mL. Kadar minimal masing-masing subjek adalah $8,60 \mathrm{pg} / \mathrm{mL}$ (TP) dan 19,19 pg/mL, sedangkan kadar maksimalnya adalah 187,24 pg/mL (TP) dan 512,22 pg/mL (SEB).

Pada kelompok kontrol kadar IL-18 dari supernatan hasil kultur limfosit, berturutturut adalah 33,36 pg/mL untuk yang sebelum diberikan paparan (TP) dan 54,19 pg/mL untuk yang dipapar dengan SEB. Kadar minimal masing-masing subjek adalah $8,60 \mathrm{pg} / \mathrm{mL}$ (TP) dan 9,33 pg/mL, sedangkan kadar maksimalnya adalah $142,62 \mathrm{pg} / \mathrm{mL}$ (TP) dan 274,02 pg/mL (SEB). Berdasarkan perhitungan statistik uji Mann Whitney maka kadar IL-18 penderita DA lebih tinggi bermakna dibanding kontrol untuk semua parameter. Baik untuk TP dan SEB nilai $\mathrm{p}=0,05$.

\section{Pembahasan}

Pada penelitian ini penderita DA wanita lebih banyak dibanding dengan laki-laki, tetapi perbedaan ini secara statistik tidak bermakna (Tabel 1). Beberapa penelitian di luar negeri seperti di Kairo pada tahun 2005 melaporkan bahwa dari 30 orang penderita DA yang diteliti, lebih banyak laki-laki. ${ }^{4}$ Novak dkk. ${ }^{5}$ melaporkan dari 225 penderita DA yang diteliti, usia ratarata adalah 30,8 tahun, laki-laki $45 \%$ dan wanita $55 \%$, tetapi perbedaan ini tidak bermakna. ${ }^{5}$

Kadar IL-18 penderita DA dari kultur limfosit dengan paparan SEB rata-rata adalah 99,38 pg/mL, sedangkan pada kontrol rata-rata adalah 54,18 pg/mL. Perbedaan ini bermakna

Tabel 4 Perbandingan Kadar IL-18 Kultur Limfosit Kelompok Kontrol antara TP dan SEB

\begin{tabular}{lccc}
\hline & \multicolumn{3}{c}{ Kadar IL-18 (pg/mL) } \\
\cline { 2 - 4 } & TP & SEB & Kemaknaan \\
\hline Rata-rata & 33,36 & 54,19 & $\mathrm{Z}=-1,456^{\mathrm{a}}$ \\
Simpangan baku & 29,75 & 60,58 & $\mathrm{p}=0,145$ \\
\hline
\end{tabular}

Keterangan: $\mathrm{TP}=$ sebelum diberikan paparan, $\mathrm{SEB}=$ setelah diberikan paparan $\mathrm{SEB}, \mathrm{p}=$ kemaknaan

Tabel 5 Perbandingan Kadar IL-18 Kultur Limfosit Kelompok DA dan Kontrol

\begin{tabular}{lccc}
\hline & \multicolumn{3}{c}{ Kadar IL-18 (pg/mL) } \\
\cline { 2 - 4 } & DA & Kontrol & Kemaknaan \\
\hline TP & 54,62 & 33,36 & 0,036 \\
SEB & 99,38 & 54,19 & 0,041 \\
\hline
\end{tabular}

Keterangan: $\mathrm{TP}=$ sebelum diberikan paparan, $\mathrm{SEB}=$ setelah diberikan paparan $\mathrm{SEB}, \mathrm{p}=$ kemaknaan 
Tabel 6 Perbandingan Kadar IL-18 Kultur Limfosit Kelompok DA dengan Kontrol

\begin{tabular}{|c|c|c|c|c|}
\hline & \multicolumn{4}{|c|}{ Kadar IL-18 (pg/mL) } \\
\hline & \multicolumn{2}{|c|}{ TP } & \multicolumn{2}{|c|}{ SEB } \\
\hline & DA & Kontrol & DA & Kontrol \\
\hline Rata-rata & 54,62 & 33,36 & 99,38 & 54,19 \\
\hline Simpang baku & 42,18 & 29,75 & 112,74 & 60,58 \\
\hline Minimal & 8,60 & 8,60 & 19,19 & 9,33 \\
\hline Maksimal & 187,24 & 142,62 & 512,22 & 274,02 \\
\hline
\end{tabular}

Keterangan: TP = sebelum diberikan paparan, $\mathrm{SEB}$ = setelah diberikan paparan SEB, $\mathrm{p}$ = kemaknaan

$(\mathrm{p}<0,05)$. Berdasarkan data tersebut maka dapat disimpulkan bahwa kadar IL-18 yang meningkat pada kelompok DA merupakan suatu petanda eksaserbasi pada DA yang dipapar oleh SEB. Zedan dkk. $^{6}$ dalam penelitiannya melaporkan bahwa kadar IL-18 pada pasien DA lebih tinggi dari pada kontrol. Hal ini mendukung asosiasi antara IL-18 dan DA. Trzeciak dkk. ${ }^{7}$ dalam penelitiannya melaporkan bahwa kadar IL-18 pada pasien DA lebih tinggi daripada kontrol. Selain itu, dilaporkan pula bahwa kadar IL-18 pada DA derajat berat lebih tinggi daripada DA derajat sedang. ${ }^{7}$

Novak dkk. ${ }^{5}$ melaporkan peningkatan IL-18 dari PBMC penderita DA setelah paparan dengan SEB dan terdapat perbedaan yang bermakna dibanding dengan subjek normal. Penelitian lain yang bertujuan menilai respons proliferasi PBMC dan kadar IL-18 terhadap SEA dan SEB pada 38 orang penderita DA dewasa yang dilakukan pada tahun 2009, kadar IL-18 pada supernatan PBMC penderita DA lebih tinggi dibanding dengan 33 orang kontrol. ${ }^{8}$ Sonesson dkk. ${ }^{9}$ pada penelitiannya melaporkan bahwa terdapat korelasi antara tingginya kadar IL-18 pada pasien DA yang telah disensitisasi oleh SEB. ${ }^{9}$

Interleukin-18 merupakan sitokin inflamasi yang memegang peran penting pada inflamasi kulitpenderita DA sehingga terjadi inflamasi yang konstan. Pada fase akut, sekresi sitokin Th-2 lebih dominan, sedangkan pada fase kronik sitokin Th-1 dominan. S. aureus, menstimulasi induksi produksi sitokin Th-1 pada DA, mengubah pola respons imun dan gambaran klinis penyakit. Hal ini terjadi karena $S$. aureus akan menyebabkan kadar IL-18 meningkat dengan memicu Th- $1 .{ }^{10}$ Selain itu, pada penderita atopik juga terjadi polimorfisme gen-IL18. ${ }^{11}$

Dermatitis atopik (DA) merupakan penyakit peradangan kulit kronik dengan prevalensi tinggi dan patogenesis yang kompleks. Kulit penderita DA biasanya terdapat eksotoksinnya kolonisasi $S$. aureus antara lain SEB akan menstimulasi dan juga meningkatkan inflamasi. Beberapa sitokin memegang peranan yang penting pada ketidakseimbangan Th-1 dengan Th-2. Kolonisasi S. aureus akan menyebabkan eksaserbasi DA. ${ }^{12}$ Interleukin-18 atau IL-18 merupakan sitokin proinflamasi yang diduga kuat memiliki peran penting pada inflamasi kulit penderita DA. ${ }^{13}$ Interleukin-18 (IL-18) diketahui juga sebagai regulator penting dari produksi sitokin Th-1 dan Th-2 pada penyakit atopik. Perannya pada sel Th- 1 adalah menginduksi IFN- $\gamma$ bekerja sinergis dengan IL-12 dan memperberat gejala DA. Peran Th-2 adalah menginduksi produksi IgE. Pada fase akut sekresi sitokin Th-2 lebih dominan, sedangkan Th-1 lebih dominan terhadap fase kronik. S. aureus menstimulasi induksi produksi sitokin Th-1 pada DA yang akan mengubah pola respons dan gejala klinis penyakit. $S$. aureus akan menyebabkan kadar IL-18 meningkat dan berkontribusi pada lesi kronik. Induksi super Th-1 perlu distimulus IL-18 dan blokade IL-18 mungkin dapat mencegah DA. ${ }^{3}$

Interleukin-18 (IL-18) memiliki kemampuan untuk meningkatkan respons Th-1 dan juga Th2 , bergantung pada lingkungan sitokinnya. ${ }^{14}$ Penelitian Kim dkk. $^{15}$ juga memperlihatkan peningkatan IL-1 $\alpha$ dan IL-1 $\beta$ dari keratinosit yang dipapar oleh SEB dibanding dengan kulit orang normal, khususnya pada penderita dengan kadar IgE total $>250 \mathrm{IU} / \mathrm{mL}^{16}$

Simpulan, bahwa kadar IL-18 meningkat tinggi pada kelompok DA yang dipapar SEB.

\section{Daftar Pustaka}

1. Leung DYM, Eichenfield LF, Boguniewicz M. Atopic dermatitis (atopic exzema). Dalam: 
Goldsmith LA, Katz SI, Gilchrest BA, Paller AS, Leffell DJ, Wolf K., penyunting. Fitzpatrick's dermatology in general medicine. Edisi ke-8. New York: McGraw Hill; 2012. hlm. 165-82.

2. Bieber T. Mechanism of disease atopic dermatitis. N Engl J Med. 2008;358(1):148394.

3. Terada M, Tsutsui H, Imai Y, Yasuda K, Mizutani H, Yamanishi K, dkk. Contribution of IL-18 to atopic-dermatitis-like skin inflammation induced by Staphylococcus aureus product in mice. Proc Natl Acad Sci USA. 2006;103(23):8816-21.

4. Ragab MS, Essmat SM, Bassiouny DA, AbdelHalim MRE, El-Hadidi HH, El-Sharkawy NM, dkk. Effect of staphylococcal colonization and exotoxin production on apoptosis in atopic dermatitis. J Egypt Wom Dermatol Soc. 2005;2(1):17-24.

5. Novak N, Kruse S, Potreck J, Maintz L, Jenneck C, Weidinger S, dkk. Single nucleotide polymorphisms of the IL-18 gene are associated with atopic eczema.J Allergy Clin Immunol. 2005;115(4):828-33.

6. Zedan K, Rasheed Z, Farouk Y, Alzolibani AA, Saif GB, Ismail HA, dkk. Immunoglobulin E, interleukin-18 and interleukin-12 in patients with atopic dermatitis: correlation with disease activity. J Clin Diagn Res. 2015; 9(4):WC01-5.

7. Trzeciak M, Gleń J, Bandurski T, SokołowskaWojdyło M, Wilkowska A, Roszkiewicz J. Relationship between serum levels of interleukin-18, IgE and disease severity in patients with atopic dermatitis. Clin Exp Dermatol. 2011;36(7):728-32.

8. Chernyshov P. Costimulatory pathway in children with atopic dermatitis and its connection with immunoglobulin E, intracellular interleukin-4 and interferongamma production by $\mathrm{T}$ cells during 1-month follow-up. J Eur Acad Dermatol Venereol. 2009;23(6):656-9.

9. Sonesson A, Bartosik J, Christiansen J, Roscher I, Nilsson F, Schmidtchen A, dkk. Sensitization to skin-associated microorganisms in adult patients with atopic dermatitis is of importance for disease severity. Acta Derm Venereol. 2013;93(3):340-5.

10. Orfali RL, Sato MN, Takaoka R, Azor MH, Rivitti EA, Hanifin JM, dkk. Atopic dermatitis in adults: evaluation of peripheral blood mononuclear cells proliferation response to Staphylococcus aureus enterotoxins A and B and analysis of interleukin-18 secretion. Exp Dermatol. 2009;18(7):628-33.

11. Attab KA, Al-Qaoud KM, Al-Bataieneh K, Ajlouni MJ. Association of SNP in the IL-4, IL-18 and eotaxin genes with asthma in a jordanian population. Int. J IntegBiol. 2008; $4(2): 86-91$.

12. Novak $\mathrm{N}$. New insights into the mechanism and management of allergic diseases: atopic dermatitis. Allergy. 2009;64(2):265-75.

13. Higgs BW, Dileo J, Chang WE, Smith HB, Peters OJ, Hammamieh R, dkk. Modeling the effects of a Staphylococcal enterotoxin B (SEB) on the apoptosis pathway. BMC Microbiol. 2006;31;6(1):48-59.

14. Lee KS, Kim SR, Park SJ, Min KH, Lee KY, Jin SM, dkk. Antioxidant down-regulates interleukin-18 expression in asthma. Mol Pharmacol. 2006;70(4):1184-93.

15. Kim KH, Han JH, Chung JH, Cho KH, Eun HC. Role of staphylococcal superantigen in atopic dermatitis: influence on keratinocytes. J Korean Med Sci. 2006;21(2):315-23.

16. Ando M, Shima M. Serum interleukins 12 and 18 and immunoglobulin $\mathrm{E}$ concentrations and allergic symptoms in japanese schoolchildren. J Investig Allergol Clin Immunol. 2007;17(1):14-9. 